\title{
Vitamin E Mempertahankan Kemampuan EPC yang Dipapar Glukosa Tinggi dalam Pelepasan NO dan Induksi Migrasi Sel Endotel
}

\section{Vitamin E Protects the Ability of High Glucose Stimulated EPC's to Release NO and Induce Endothelial Cells Migration}

\author{
Dian Nugrahenny ${ }^{1}$, M Aris Widodo², Nur Permatasari ${ }^{2}$ \\ ${ }^{1}$ Laboratorium Farmakologi Fakultas Kedokteran Universitas Brawijaya Malang \\ ${ }^{2}$ Laboratorium Ilmu Farmakologi Fakultas Kedokteran Universitas Brawijaya Malang
}

\begin{abstract}
ABSTRAK
Peran sel progenitor endotel (EPC) dalam angiogenesis terganggu pada diabetes. Penelitian dilakukan untuk mengamati efek vitamin E pada kemampuan EPC yang dipapar glukosa tinggi dalam melepaskan NO dan menginduksi migrasi sel endotel. Sel mononuklear diisolasi dari darah perifer subjek sehat. Pada hari ke-7, kultur EPC diberikan glukosa normal (5 $\mathrm{mM}$ ) dengan atau tanpa pemberian vitamin E $22 \mu \mathrm{M}$ atau $50 \mu \mathrm{M}$ sebagai kontrol, atau diberikan glukosa tinggi (22 mM) dengan atau tanpa pemberian vitamin E $22 \mu \mathrm{M}$ atau $50 \mu \mathrm{M}$ selama 24 jam. Fungsi EPC dinilai dengan mengevaluasi migrasi HUVEC setelah pemberian supernatan EPC. Migrasi HUVEC dinilai dengan uji migrasi wound-healing. Konsentrasi NO dan $\mathrm{H}_{2} \mathrm{O}_{2}$ EPC diukur dengan uji kolorimetrik. Superoksid EPC dinilai dengan uji NBT. Pemberian glukosa tinggi mengakibatkan penurunan kemampuan EPC dalam menginduksi migrasi HUVEC, penurunan NO EPC, serta peningkatan superoksid dan $\mathrm{H}_{2} \mathrm{O}_{2}$ EPC. Pemberian vitamin E $50 \mu \mathrm{M}$ dapat menghambat penurunan kemampuan EPC dalam menginduksi migrasi HUVEC, dan efek ini terkait dengan konsentrasi NO, superoksid dan $\mathrm{H}_{2} \mathrm{O}_{2}$ EPC. Pemberian vitamin $E$ dapat mempertahankan kemampuan EPC yang dipapar glukosa tinggi dalam melepaskan NO dan menginduksi migrasi HUVECs melalui hambatan peningkatan superoksid dan $\mathrm{H}_{2} \mathrm{O}_{2}$ EPC.
\end{abstract}

Kata Kunci: EPC, glukosa tinggi, NO, ROS, vitamin E

\section{ABSTRACT}

Role of EPCS on angiogenesis is impaired in diabetes. Study was designed to investigate effect of vitamin E toward ability of high glucose (HG) stimulated EPCs to release NO and inducemigration of endothelial cells. Mononuclear cells were isolated from healthy subjects. After 7 days of culture, EPCs were cultured in $5 \mathrm{mM}$ normal glucose in the absence or presence of 22 $\mu \mathrm{M}$ or $50 \mu \mathrm{M}$ vitamin $E$, or cultured in $22 \mathrm{mM} \mathrm{HG}$ in the absence or presence of $22 \mu \mathrm{M}$ or $50 \mu \mathrm{M}$ vitamin Efor 24 hours. EPCs function was assessed by evaluating HUVECs migration after administration of EPCs supernatant that had previously been treated. HUVECs migration was evaluated using wound-healing migration assay. The levels of $\mathrm{NO}$ and $\mathrm{H}_{2} \mathrm{O}_{2}$ inEPCS supernatant were measured by colorimetric assay. Superoxide of EPCS was evaluated by NBT assay. HG impaired EPCS ability to induce migration of HUVECs. Effect of HG could be reversed by co incubation with $50 \mu M$ vitamin E. Effect of vitamin $\mathrm{E}$ on ability of EPCS was correlated with EPCs levels of $\mathrm{NO}$, superoxide and $\mathrm{H}_{2} \mathrm{O}_{2}$. It can be concluded that Vitamin $E$ could maintain the ability of HG stimulated EPCS to release NO and induce migration of HUVECs through ROS-related mechanisms.

Keywords: EPCs, high glucose, NO, ROS, vitamin E

Jurnal Kedokteran Brawijaya, Vol. 27 No. 1, Februari 2012; Korespondensi: Dian Nugrahenny. Laboratorium Farmakologi Fakultas Kedokteran Universitas Brawijaya Malang, Jl. Veteran Malang Tel. (0341) 596117 Email: diannugrahenny@ymail.com 


\section{PENDAHULUAN}

Diabetes mellitus (DM) merupakan kelainan endokrin yang banyak dijumpai di Indonesia (1). Kondisi hiperglikemia yang tidak terkontrol dapat mengakibatkan disfungsi endotel yang berperan pada terjadinya komplikasi penyakit vaskuler pada DM (2). Disfungsi endotel pada DM menyebabkan pelepasan berbagai mediator dan faktor pertumbuhan yang dapat menginduksi mobilisasi sel progenitor endotel (EPC) dari sumsum tulang (3). Sel progenitor endotel kemudian berperan dalam angiogenesis maupun vaskulogenesis. Fasilitasi angiogenesis oleh EPC dilakukan melalui aktivitas parakrin, yaitu dengan melepaskan mediator yang berperan penting pada aktivasi sel endotel matur, diantaranya Nitric oxide (NO) $(3,4,5)$. Nitric oxide diketahui dapat mempengaruhi fungsi migrasi sel endotel yang penting dalam angiogenesis, yaitu melalui regulasi positif jalur signaling vascular endothelial growth factor and receptors (VEGF)/vascular endothelial growth factor receptor-2(VEGFR2) $(6,7)$.

Pada kondisi glukosa tinggi terjadi penurunan NO akibat inaktivasi NO oleh superoksid $(8,9)$, serta hambatan ekspresi (10) maupun aktivasi endothelial nitric oxide synthase (eNOS) $(10,11)$. Penurunan NO diketahui dapat mengganggu peran VEGF dalam migrasi sel endotel (12). Pada kondisi glukosa tinggi juga terjadi peningkatan produksi reactive oxygen species (ROS) $(13,14)$. ROS dapat menghambat migrasi sel endotel, diantaranya melalui kerusakan sitoskeleton dan gangguan polimerisasi aktin (15). Pemberian donor NO (16) dan superoxyde dismutase (SOD) (15) diketahui dapat memperbaiki fungsi migrasi sel endotel. Oleh karena itu, diduga bahwa tingginya produksi ROS oleh EPC pada kondisi glukosa tinggi dapat mengganggu kemampuan EPC dalam melepaskan NO dan menginduksi migrasi sel endotel, sehingga berdampak pada gangguan angiogenesis.

Telah dibuktikan in vitro bahwa pemberian vitamin $\mathrm{E}$ dapat meningkatkan kadar NO, serta menurunkan produksi superoksid dan $\mathrm{H}_{2} \mathrm{O}_{2}$ (17). Efek tersebut terjadi karena vitamin $\mathrm{E}$ dapat menghambat aktivasi protein kinase $C$ (PKC) yang dibutuhkan untuk aktivasi nicotinamide adenine dinucleotide phosphate reducing form $\mathrm{NAD}(\mathrm{P}) \mathrm{H}$ oksidase, sumber utama $\operatorname{ROS}(17,18)$. Penelitian ini dilakukan untuk mengamati efek vitamin $E$ terhadap kemampuan EPC yang dipapar glukosa tinggi dalam melepaskan NO dan menginduksi migrasi sel endotel matur. Hal ini penting diketahui sebagai upaya optimalisasi peran EPC dalam regenerasi vaskuler melalui penggunaan antioksidan, khususnya pada kasus komplikasi vaskuler DM.

\section{METODE}

\section{Rancangan Penelitian}

Rancangan penelitian berupa randomized posttest only control group design, dengan 6 kelompok perlakuan: (1) EPC dipapar glukosa $5 \mathrm{mM}$ tanpa pemberian vitamin $\mathrm{E}(\mathrm{N})$, (2) EPC dipapar glukosa $5 \mathrm{mM}$ dan diberikan vitamin E 22 $\mu \mathrm{M}$ (E22), (3) EPC dipapar glukosa $5 \mathrm{mM}$ dan diberikan vitamin E $50 \mu \mathrm{M}$ (E50), (4) EPC dipapar glukosa $22 \mathrm{mM}(\mathrm{G})$, (5) EPC dipapar glukosa $22 \mathrm{mM}$ dan diberikan vitamin E 22 $\mu \mathrm{M}(\mathrm{E} 22+\mathrm{G})$, dan (6) EPC dipapar glukosa $22 \mathrm{mM}$ dan diberikan vitamin E $50 \mu \mathrm{M}(\mathrm{E} 50+\mathrm{G})$. Perlakuan diberikan selama 24 jam. Semua eksperimen dilakukan dalam 5 kali replikasi. Penelitian telah disetujui oleh Komisi Etik Fakultas Kedokteran Universitas Brawijaya.

\section{Isolasidan KulturEPC}

Sel mononuklear diisolasi dari darah perifer subjek dewasa muda yang sehat dengan cara sentrifugasi gradien densitas menggunakan media separasi limfosit (densitas 1,077 g/ml; MP Biomedicals). Sel yang terisolasi ditanam dalam media kultur M199 (Invitrogen Corp.) yang mengandung $100 \mathrm{IU} / \mathrm{ml}$ penisilin (Sigma), $100 \mathrm{\mu g} / \mathrm{ml}$ streptomisin (Sigma), 20\% fetal bovine serum (FBS) (Invitrogen Corp.), $10 \mathrm{ng} / \mathrm{ml}$ human epidermal growth factors (hEGF) (Sigma), dan $100 \mu \mathrm{g} / \mathrm{ml}$ endothelial cell growth factors (ECGF) (Sigma). Sel ditanam dalam piringan 48 -sumur yang telah dilapisi gelatin $1 \%$, kemudian diinkubasi $\left(\mathrm{CO}_{2} 5 \%, 37^{\circ} \mathrm{C}\right)$. Media kultur diganti setiap 3 hari $(19,20,21)$. Morfologi sel diamati setiap hari.

\section{Karakterisasi EPC}

Dilakukan pengecatan imunofluoresensi, yaitu sel diinkubasi $\left(\mathrm{CO}_{2} 5 \%, 37^{\circ} \mathrm{C}, 1 \mathrm{jam}\right)$ dengan $10 \mu \mathrm{g} / \mathrm{mL}$ Dil-acLDL (Biomedical Technologies), difiksasi dengan paraformaldehid $2 \%$, kemudian diinkubasi dengan 50 $\mu \mathrm{g} / \mathrm{mL}$ UEA-lectin yang dilabel FITC (Sigma) selama 45 menit. Dilakukan pengecatan imunohistokimia untuk mengamati ekspresi vWF (Santa Cruz) pada late EPC (21).

\section{Perlakuan}

Pada hari ke-7, media kultur diganti dengan media yang mengandung $22 \mathrm{mM}$ D-(+)-glukosa (Sigma), kemudian sel diinkubasi $\left(\mathrm{CO}_{2} 5 \%, 37^{\circ} \mathrm{C}, 24 \mathrm{jam}\right)(22)$. Vitamin $\mathrm{E}(\mathrm{d}-\alpha-$ tokoferol; Sigma) $22 \mu \mathrm{M}$ atau $50 \mu \mathrm{M}$ dengan konsentrasi akhir pelarut etanol $<0,5 \%$ diberikan bersamaan dengan pemaparan glukosa. Sebagai kontrol, pada media kultur tanpa penambahan vitamin $\mathrm{E}$ juga ditambahkan etanol dengan konsentrasi sama(22,23).

Isolasi dan Kultur Human Umbilical Vein Endothelial Celss (HUVEC)

Umbilikus diperoleh dari proses persalinan normal dari ibu dan bayi yang sehat. Sel endotel diisolasi dari umbilikus dengan cara inkubasi $\left(37^{\circ} \mathrm{C}, 8\right.$ menit) dengan kolagenase tipe II (Sigma). Sel yang terisolasi ditanam dalam media kultur M199 (Invitrogen Corp.) yang mengandung 100 $\mathrm{IU} / \mathrm{ml}$ penisilin (Sigma), $100 \mathrm{\mu g} / \mathrm{ml}$ streptomisin (Sigma), dan 10\% FBS (Invitrogen Corp.). Sel ditanam dalam piringan 24-sumur yang telah dilapisi gelatin $0,2 \%$, kemudian diinkubasi $\left(\mathrm{CO}_{2} 5 \%, 37^{\circ} \mathrm{C}\right)$. Media kultur diganti setiap 3 hari. Kultur sel endotel menjadi satu lapis dalam waktu 4-5 hari dan siap diberi perlakuan(24).

\section{Pengukuran parameter}

Pemeriksaan kadar NO dilakukan dengan mengambil media kultur EPC kemudian partikulat pada media dihilangkan dengan filtrasi. Analisis NO dilakukan menggunakan Griess reaction kit secara kolorimetri sesuai prosedur dari R\&D system. Hasil densitas optik dibaca pada $570 \mathrm{~nm}$ dengan microplate-reader.

Pemeriksaan superoksid dilakukan secara tidak langsung dengan menilai densitas formazan (granula biru-ungu tua), hasil reduksi NBT (nitroblue tetrazolium) oleh radikal superoksid. Pada EPC ditambahkan larutan NBT 0,1\% dengan volume sama, kemudian diinkubasi $\left(\mathrm{CO}_{2} 5 \%, 37^{\circ} \mathrm{C}\right.$, 30 menit). Deposit formazan dinilai pada 100 sel. Pengamatan dilakukan secara double-blind oleh 2 orang observer pada perbesaran 200x menggunakan mikroskop inverted yang terhubung komputer. Skor untuk deposit formazan sebagai berikut: negatif bila deposit formazan tidak ada, menyebar atau melingkupi $<50 \%$ bagian sel; dan positif bila deposit formazan melingkupi $\geq 50 \%$ bagian sel (25). 
Untuk mengukur kadar $\mathrm{H} 2 \mathrm{O} 3 \mathrm{~m}$ media kultur EPC diambil dan partikulat pada media dihilangkan dengan filtrasi. Analisis $\mathrm{H}_{2} \mathrm{O}_{2}$ dilakukan menggunakan $\mathrm{H}_{2} \mathrm{O}_{2}$ assaykit dengan metode HRP secara kolorimetri sesuai prosedur dari Biovision. Hasil densitas optik dibaca pada $570 \mathrm{~nm}$ dengan microplate-reader.

Fungsi EPC dinilai dengan mengevaluasi migrasi sel endotel (HUVECs) setelah pemberian supernatan kultur EPC yang sebelumnya telah diberi perlakuan. Setelah perlakuan 24 jam, media EPC diganti dengan media bebas serum, kemudian diinkubasi ( $\left.\mathrm{CO}_{2} 5 \%, 37 \mathrm{C}, 24 \mathrm{jam}\right)$. Media ini disebut EPC-conditioned media (EPC-CM). EPC-CM diambil kemudian difiltrasi untuk mendapatkan EPC-CM bebas sel.Media HUVECs diganti dengan media bebas serum, dan diinkubasi $\left(\mathrm{CO}_{2} 5 \%, 37 \mathrm{C}, 4\right.$ jam). HUVECs monolayer digores dengan ujung pinset, membentuk zona bebas sel dengan lebar $\pm 1 \mathrm{~mm}$. Debris seluler dibersihkan, kemudian EPC-CM dipaparkan pada HUVECs dan diinkubasi $\left(\mathrm{CO}_{2} 5 \%, 37 \mathrm{C}, 24\right.$ jam) $(26,27)$. Migrasi HUVECs dinilai dengan mengukur prosentase penyempitan lebar zona bebas sel, dengan rumus: \% migrasi HUVECs=100-([x/y]x100)\%. Notasi $x$ adalah lebar zona bebas sel setelah perlakuan, dan y adalah lebar zona bebas sel sebelum perlakuan. Pengamatan dilakukan pada perbesaran 40x menggunakan mikroskop inverted yang terhubung komputer. Data dianalisis dengan ANOVA dan uji korelasi Pearson dengan tingkat signifikansi $p<0,05$ menggunakan program SPSS 16,0 for Windows.

\section{HASIL}

\section{Karakterisasi EPC}

Pada saat awal ditanam dalam media kultur, sel berbentuk bulat (Gambar 1A). Pada hari ke-3 mulai terbentuk koloni khas EPC, dengan bagian tengah koloni berkumpul sel-sel berbentuk bulat, dan pada bagian tepi koloni sel-sel mulai menipis, memipih dan memanjang menjadi bentuk spindle dan bergerak menyebar menjauhi koloni (Gambar 1B-C). Pada hari ke-14 didapatkan beberapa EPC berdiferensiasi menjadi sel endotel matur yang berbentuk cobblestone. Didapatkan aktivitas proliferasi pada EPC yang ditandai dengan adanya sel dengan inti lebih dari satu (Gambar 1D).

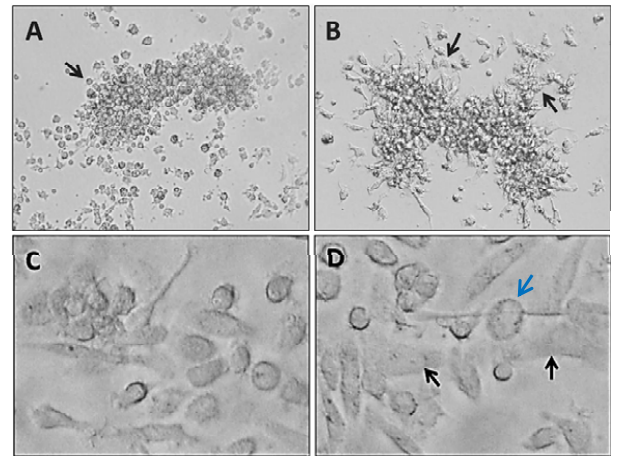

Gambar 1. Karakterisasi morfologi EPC

Keterangan:

A. EPC hari ke-1. B. EPC hari ke-3 (sprouting, tanda panah). Perbesaran $100 \times$ C. EPC hari ke-7. D. EPC hari ke-14 cobblestone (tanda panah hitam) sel multinukleus (tanda panah biru). Perbesaran 200x.

Pengecatan imunofluoresensi pada sel hari ke-7 menunjukkan fenotip sel endotel, yaitu adanya uptake Dil-
ac-LDL dan pengikatan UEA-lectin (Gambar 2A-D). Pengecatan imunohistokimia pada sel hari ke-7 menunjukkan adanya ekspresi marker sel endotel matur, yaitu vWF (Gambar 2E). Oleh karena itu sel dapat dikategorikan sebagai late EPC.

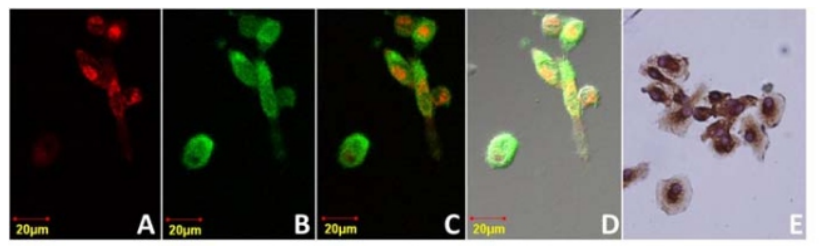

Gambar 2. Karakterisasi EPC hari ke-7 dengan Dil-ac-LDL, UEAlectin, dan vWF.

Keterangan:

A. Uptake Dil-ac-LDL (fluoresensi berwarna merah pada sel)

B. Pengikatan FITC-UEA-lectin (fluoresensi berwarna hijau pada sel)

C. Sel double-positif Dil-ac-LDL dan FITC-UEA-lectin yang ditunjukkan dengan fluoresensi berwarna jingga

D. Superimposed fluoresensi pada sel

E. vWF (warna coklat pada sel)

Efek Vitamin E terhadap Penurunan Konsentrasi NO pada EPC yang Dipapar Glukosa Tinggi

Pemaparan glukosa $22 \mathrm{mM}$ pada kultur EPC menyebabkan konsentrasi NO EPC $(G=2,88 \pm 0,102 \mu \mathrm{M})$ menurun secara bermakna $(p<0,05)$ dibandingkan normal $(\mathrm{N}=3,75 \pm 0,102$ $\mu \mathrm{M})$. Pemberian vitamin E $50 \mu \mathrm{M}$ pada kultur EPC yang dipapar glukosa $22 \mathrm{mM}$ mampu menghambat penurunan konsentrasi NO EPC $(E 50+G=3,59+0,020 \mu \mathrm{M})$ secara bermakna $(p<0,05)$ dibanding kelompok glukosa, dengan konsentrasi yang tidak berbeda bermakna $(p>0,05)$ bila dibanding kelompok normal (Gambar 3).

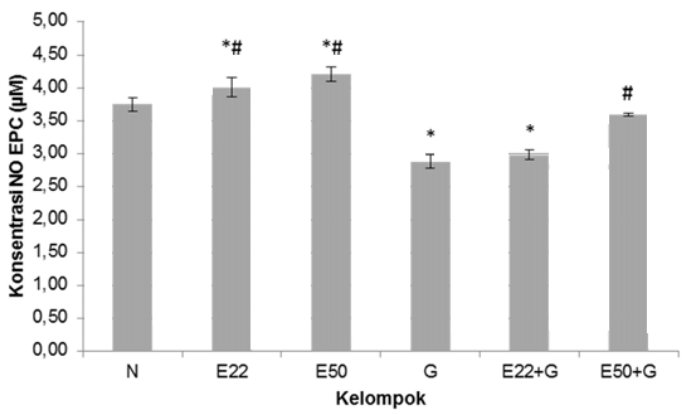

Gambar 3. Konsentrasi NO EPC di masing-masing perlakuan Keterangan:

Konsentrasi NO pada supernatan kultur EPC dievaluasi secara tidak langsung dengan metode kolorimetri menggunakan reaksi Griess

Pemaparan glukosa $22 \mathrm{mM}$ pada kultur EPC menyebabkan konsentrasi NO EPC $(G=2,88 \pm 0,102 \mu \mathrm{M})$ menurun secara bermakna $(p<0,05)$ dibandingkan normal $(\mathrm{N}=3,75 \pm 0,102$ $\mu \mathrm{M})$. Pemberian vitamin E $50 \mu \mathrm{M}$ pada kultur EPC yang dipapar glukosa $22 \mathrm{mM}$ mampu menghambat penurunan konsentrasi NO EPC $(E 50+G=3,59 \pm 0,020 \mu M)$ secara bermakna $(p<0,05)$ dibanding kelompok glukosa, dengan konsentrasi yang tidak berbeda bermakna $(p>0,05)$ bila 
dibanding kelompok normal (Gambar 3).

Pemaparan glukosa $22 \mathrm{mM}$ pada kultur EPC menyebabkan prosentase EPC dengan NBT positif ( $G=65,80 \pm 2,588 \%)$ meningkat secara bermakna $(p<0,05)$ dibandingkan normal $(\mathrm{N}=12,40 \pm 1,817 \%)$. Pemberian vitamin E $22 \mu \mathrm{M}$ dan $50 \mu \mathrm{M}$ pada kultur EPC yang dipapar glukosa $22 \mathrm{mM}$ mampu menghambat peningkatan prosentase EPC dengan NBT positif (E22+G=47,80+1,924\%; $\mathrm{E} 50+\mathrm{G}=18,80 \pm 2,588 \%)$ secara bermakna $(p<0,05)$ dibanding kelompok glukosa (Gambar 4).

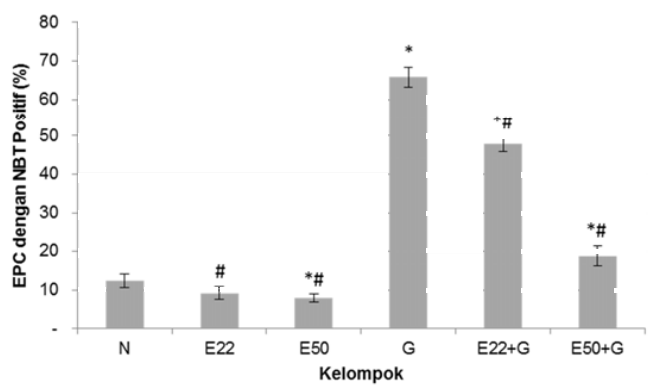

Gambar 4. Prosentase EPC dengan NBT positif di masingmasing kelompok

Keterangan:

Data pada diagram ditampilkan dalam mean \pm SD; $n=5 ; * p<0,05$ dibandingN; \# $p<0,05$ dibanding G. N, EPC dipapar glukosa $5 \mathrm{mM}$ tanpa pemberian vitamin E. E22, EPC dipapar glukosa $5 \mathrm{mM}$ dan diberikan vitamin E $22 \mu \mathrm{M}$. E50, EPC dipapar glukosa $5 \mathrm{mM}$ dan diberikan vitamin $\mathrm{E}$ 50 MM. G, EPC dipapar glukosa 22 mM. E22+G, EPC dipapar glukosa 22 $\mathrm{mM}$ dan diberikan vitamin E $22 \mu \mathrm{M}$. E50+G, EPC dipapar glukosa $22 \mathrm{mM}$ dan diberikan vitamin $\mathrm{E} 50 \mu \mathrm{M}$.

Pemaparan glukosa $22 \mathrm{mM}$ pada kultur EPC menyebabkan konsentrasi $\mathrm{H}_{2} \mathrm{O}_{2}$ EPC $\left(\mathrm{G}=6,01 \cdot 10^{-5} \pm 0,422 \cdot 10^{-5} \mu \mathrm{M}\right)$ meningkat secara bermakna $(p<0,05)$ dibandingkan normal $\left(\mathrm{N}=2,59 \cdot 10^{-5} \pm 0,008 \cdot 10^{-5} \mu \mathrm{M}\right)$. Pemberian vitamin $\mathrm{E}$ $22 \mu \mathrm{M}$ dan $50 \mu \mathrm{M}$ pada kultur EPC yang dipapar glukosa 22 mM mampu menghambat peningkatan konsentrasi $\mathrm{H}_{2} \mathrm{O}_{2}$ EPC $\left(E 22+G=3,92 \cdot 10^{-5} \pm 0,033 \cdot 10^{-5} \mu \mathrm{M} ; \quad E 50+G=2,69 \cdot 10^{-}\right.$ $\left.\pm 0,070.10^{-5} \mu \mathrm{M}\right)$ secara bermakna $(p<0,05)$ dibanding kelompok glukosa (Gambar 5).

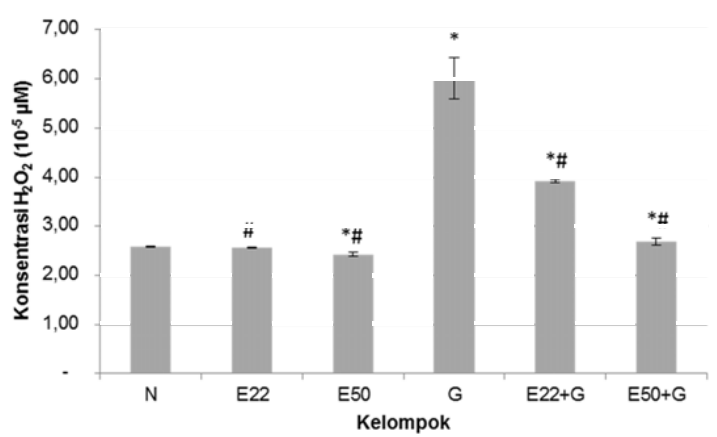

Gambar 5. Uji Konsentrasi H2O2 pada masing-masing perlakuan

Keterangan:

Konsentrasi $\mathrm{H}_{2} \mathrm{O}_{2}$ pada supernatan kultur EPC dievaluasi dengan metode kolorimetri. Data pada diagram ditampilkan dalam mean $\pm \mathrm{SD} ; n=5 ;{ }^{*} p<$ 0,05 dibandingN; \# $p<0,05$ dibanding G. N, normal; E22, vitamin E 22 $\mu \mathrm{M}$; E50, vitamin E $50 \mu \mathrm{M}$; G, glukosa $22 \mathrm{mM}$; E22+G, vitamin E $22 \mu \mathrm{M}$ dan glukosa $22 \mathrm{mM}$; E50+G, vitamin E $50 \mu \mathrm{M}$ dan glukosa $22 \mathrm{mM}$.
Vitamin E Menghambat Penurunan Kemampuan EPC yang Dipapar Glukosa Tinggi dalam Menginduksi Migrasi HUVECS

Kemampuan migrasi HUVECs dinilai dengan menghitung prosentase penyempitan lebar zona bebas sel setelah diinkubasi dengan supernatan kultur EPC selama 24 jam.

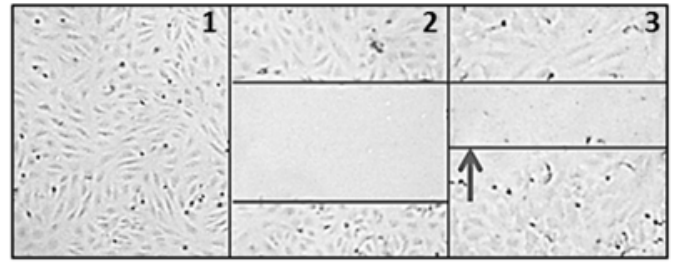

Gambar 6. Uji migrasi scratch/wound healing Keterangan:

HUVECs sesaat setelah digores dengan ujung pinset untuk membuat zona bebas sel (2), dan HUVECs setelah diinkubasi dengan supernatan kultur EPC selama 24 jam (3). Garis merah adalah batas zona bebas sel yang ditentukan dengan menarik garis dari minimal 3 sel pada tepi zona bebas sel. Tanda panah biru menunjukkan jarak migrasi HUVECs.

Pemaparan glukosa 22 mM pada kultur EPC menyebabkan prosentase migrasi HUVECs setelah diberikan supernatan kultur EPC (G=6,28 $\pm 0,192 \%)$ menurun secara bermakna $(p<0,05)$ dibandingkan normal $(\mathrm{N}=18,64 \pm 0,167 \%)$. Pemberian vitamin E $22 \mu \mathrm{M}$ dan $50 \mu \mathrm{M}$ pada kultur EPC yang dipapar glukosa $22 \mathrm{mM}$ mampu menghambat penurunan prosentase migrasi HUVECs setelah diberikan supernatan kultur EPC $(E 22+G=8,32 \pm 0,618 \%$; $\mathrm{E} 50+\mathrm{G}=16,46 \pm 0,416 \%)$ secara bermakna dibanding kelompok glukosa (Gambar 7).

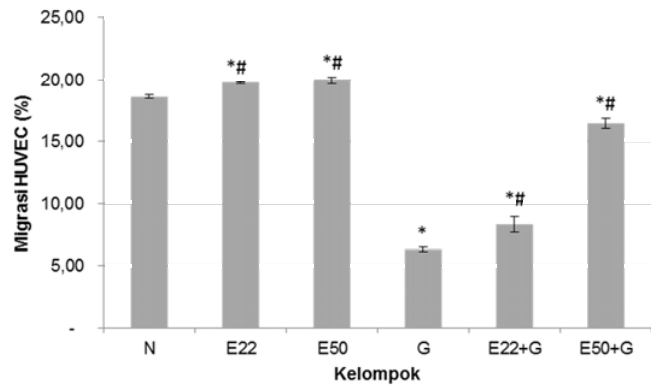

Gambar 7. Uji migrasi HUVECs pada masing-masing perlakuan Keterangan:

Data pada diagram ditampilkan dalam mean \pm SD; $n=5 ; * p<0,05$ dibandingN; \# $p<0,05$ dibanding G. N, EPC dipapar glukosa $5 \mathrm{mM}$ tanpa pemberian vitamin E. E22, EPC dipapar glukosa $5 \mathrm{mM}$ dan diberikan vitamin E $22 \mu \mathrm{M}$. E50, EPC dipapar glukosa $5 \mathrm{mM}$ dan diberikan vitamin $\mathrm{E}$ $50 \mu \mathrm{M}$. G, EPC dipapar glukosa $22 \mathrm{mM}$. E22+G, EPC dipapar glukosa 22 $\mathrm{mM}$ dan diberikan vitamin E $22 \mu \mathrm{M}$. E50+G, EPC dipapar glukosa $22 \mathrm{mM}$ dan diberikan vitamin $\mathrm{E} 50 \mu \mathrm{M}$.

Terdapat korelasi positif yang sangat kuat $(r>0,800)$ dan bermakna $(p<0,01)$ antara dosis vitamin $\mathrm{E}$ dengan konsentrasi $\mathrm{NO}$, superoksid, dan $\mathrm{H}_{2} \mathrm{O}_{2} \mathrm{EPC}$, serta migrasi HUVECs. Kemampuan migrasi HUVECs terutama terkait dengan konsentrasi NO EPC $(r=0,978)$. Konsentrasi NO EPC terutama terkait dengan superoksid EPC $(r=-0,943)$. Superoksid dan $\mathrm{H}_{2} \mathrm{O}_{2}$ EPC terkait dengan dosis vitamin $\mathrm{E}$ 
( $r=-0,985$ dan $r=-0,976$ secara berurutan). Dari data tersebut diketahui bahwa vitamin E dapat mempertahankan kemampuan EPC yang dipapar glukosa tinggi dalam melepaskan NO dan menginduksi migrasi HUVEC melalui hambatan peningkatan superoksid dan $\mathrm{H}_{2} \mathrm{O}_{2}$ EPC.

\section{DISKUSI}

Pada penelitian ini dibuktikan bahwa pemaparan glukosa tinggi selama 24 jam dapat secara bermakna menghambat kemampuan EPC dalam induksi migrasi sel endotel, dan hal ini terkait dengan penurunan NO. Nitric oxide yang disintesis oleh eNOS diketahui berperan penting sebagai regulator migrasi sel endotel dalam angiogenesis, yaitu melalui regulasi positif jalur signaling VEGF/VEGFR2. VEGFR-2 yang teraktivasi berperan memicu kaskade fosforilasi VE-cadherin pada residu tirosin yang dimediasi Src kinase. Sekuestrasi VE-cadherin pada endosom selanjutnya dapat merusak faktor adesi fokal, memicu hilangnya kontak antar sel, meningkatkan permeabilitas vaskuler, dan memicu migrasi sel endotel. Aktivasi VEGFR-2 juga memicu polimerisasi aktin dan turnover faktor adesi fokal (vinculin, paxillin, dan talin) yang berperan dalam pembentukan stress fiber. Stress fiber ini yang memungkinkan terjadinya kontraksi sel endotel dan membuat sel endotel mampu melakukan migrasi $(6,7)$. Hambatan produksi NO diketahui dapat mengganggu peran VEGF/VEGFR2 dalam migrasi sel endotel $(6,12)$.

Pada penelitian ini dibuktikan penurunan NO EPC terutama terkait dengan tingginya superoksid pada kondisi glukosa tinggi. Hal ini sejalan dengan penelitian lain yang menunjukkan adanya penurunan NO dan peningkatan superoksid pada endotel yang dipapar glukosa tinggi selama 24 jam $(28,29)$. Peningkatan superoksid tersebut terutama bersumber dari aktivasi NAD (P)H oksidase $(10,28)$ oleh PKC- $\alpha(30,31)$. Superoksid selanjutnya berinteraksi dengan NO, membentuk sitotoksin kuat, yaitu peroksinitrit $\left(\mathrm{ONOO}^{-}\right)(8,9,32)$. Peroksinitrit kemudian dapat mengoksidasi kofaktor eNOS, yaitu tetrahidrobiopterin, mengakibatkan kondisi eNOS uncouple (10), kemudian eNOS akan menggunakan oksigen sebagai substrat untuk memproduksi superoksid lebih banyak daripada NO $(10,17)$. Produksi superoksid berlebihan dapat merusak sitoskeleton sehingga akan menghambat migrasi sel endotel. Selain itu, peroksinitrit juga dapat menghambat polimerisasi aktin yang penting untuk migrasi sel endotel(15).

Penurunan NO pada kondisi glukosa tinggi juga dapat disebabkan oleh penurunan ekspresi maupun aktivasi eNOS. Pada tingkat transkripsi, superoksid dapat mengaktivasi faktor transkripsi AP-1 yang berperan dalam modulasi transkripsi mRNA eNOS (10). Pada tingkat posttranslasi, tingginya ROS dapat menyebabkan penurunan fosforilasi Ser117 eNOS $(10,11)$. Apabila ekspresi ataupun aktivitas eNOS menurun, maka produksi NO akan menurun.

Pada penelitian ini diketahui bahwa pemaparan glukosa tinggi dapat meningkatkan $\mathrm{H}_{2} \mathrm{O}_{2}$ EPC secara signifikan. Hal ini sejalan dengan penelitian yang menunjukkan adanya peningkatan produksi $\mathrm{H}_{2} \mathrm{O}_{2}$ pada sel endotel yang dipapar glukosa tinggi (33). $\mathrm{H}_{2} \mathrm{O}_{2}$ merupakan ROS stabil, produk dismutasi superoksid oleh SOD (34). Peningkatan $\mathrm{H}_{2} \mathrm{O}_{2}$ EPC pada penelitian ini terkaitdengan penurunan NO EPC maupun kemampuan EPC dalam induksi migrasi sel endotel. Hal ini sejalan dengan penelitian lain yang menunjukkan bahwa $\mathrm{H}_{2} \mathrm{O}_{2}$ dapat menghambat mekanisme perbaikan vaskuler yang diinduksi EPC pada penyakit kardiovaskuler (35).

Pada penelitian ini diberikan vitamin E, yaitu $d$ - $\alpha$-tokoferol, dosis $22 \mu \mathrm{M}$ atau $50 \mu \mathrm{M}$, bersamaan dengan pemaparan glukosa tinggi selama 24jam. Vitamin E $22 \mu \mathrm{M}$ setara dengan kadar dalam plasma dewasa normal(23). Vitamin $\mathrm{E}$ $50 \mu \mathrm{M}$ setara dengan kadar dalam plasma dewasa yang mendapat suplementasi vitamin E 400 IU per oral (36). Dibuktikan bahwa pemberian vitamin E $50 \mu \mathrm{M}$ pada EPC yang dipapar glukosa tinggi selama 24 jam mampu menghambat penurunan kemampuan EPC dalam induksi migrasi sel endotel secara signifikan, terkait dengan hambatan penurunan NO EPC serta hambatan peningkatan superoksid dan $\mathrm{H}_{2} \mathrm{O}_{2}$ EPC. Hal ini sejalan dengan penelitian in vitro yang menunjukkan bahwa pemberian vitamin E dapat meningkatkan kadar NO dan aktivitas eNOS, serta menurunkan pembentukan $\mathrm{O}_{2}{ }^{-}$dan aktivasi $\mathrm{NAD}(\mathrm{P}) \mathrm{H}$ oksidase (17). Efek tersebut diduga terjadi karena vitamin $\mathrm{E}$ mampu menghambat aktivasi PKC, sehingga dapat menghambat aktivasi $\mathrm{NAD}(\mathrm{P}) \mathrm{H}$ oksidase. Vitamin E menghambat aktivasi PKC dengan meningkatkan degradasi enzimatik DAG (sumber PKC), dan mengaktifkan fosfatase $2 \mathrm{~A}$ yang dapat mendefosforilasi PKC. Apabila aktivasi NAD(P)H oksidase dihambat, maka produksi superoksid dan $\mathrm{H}_{2} \mathrm{O}_{2}$ pada kondisi glukosa tinggi dapat dihambat $(18,30)$, selanjutnya dapat mempertahankan kemampuan EPC dalam melepaskan NO dan menginduksi migrasi sel endotel.

Efek vitamin E dalam menghambat penurunan NO pada kondisi glukosa tinggi diduga juga terkait dengan kemampuan vitamin $\mathrm{E}$ dalam melindungi membran sel dari kerusakan akibat radikal bebas. Vitamin $\mathrm{E}$ dapat menghambat peroksidasi lemak pada fosfolipid membran sel dengan cara menangkap radikal peroksil, mendonorkan atom hidrogen untuk meredam radikal peroksil tersebut, kemudian membentuk radikal tokoferoksil dengan reaktivitas yang lebih rendah (34).

Struktur membran sel yang berupa lipid bilayer dan mengandung banyak protein struktural maupun fungsional membuat stabilitas membran berperan penting dalam proses biologis seluler. Protein fungsional pada membran sel membentuk berbagai macam reseptor dan struktur penting pada membran, diantaranya caveola yang berperan sebagai sisi penangkap molekul signaling(37). eNOS terletak pada caveola. Di dalam caveola tersebut juga terdapat caveolin-1 (38). Caveolin-1 berinteraksi dengan eNOS dan meregulasi negatif aktivitas eNOS (39). Caveolin-1 juga membentuk kompleks dengan VEGFR-2 pada caveola, dan kompleks tersebut dapat dilepaskan oleh VEGF. Diketahui bahwa VEGF dapat mengaktivasi eNOS dengan melepaskan eNOS dari ikatan dengan caveolin-1 (40). Penelitian lain menunjukkan bahwa eNOS tidak dapat diaktivasi dengan tepat pada sel endotel apabila caveola rusak, dan hal ini mempengaruhi produksi NO $(41,42)$. Aksi vitamin E dalam menjaga stabilitas membran sel diduga dapat mempertahankan struktur dan fungsi caveola pada membran EPC, sehingga dapat mempertahankan aktivasi eNOS dan pelepasan NO EPC yang berperan pada kemampuan EPC dalam menginduksi 
migrasi sel endotel.

Penelitian ini membuktikan bahwa suplementasi vitamin E dengan dosis $50 \mu \mathrm{M}$ pada EPC yang dipapar glukosa tinggi selama 24 jam mampu mempertahankan kemampuan EPC dalam melepaskan NO dan menginduksi migrasi sel endotel terkait dengan ROS EPC. Meskipun demikian, penggunaan vitamin E secara klinis perlu dipertimbangkan karena telah berkembang semakin banyak penelitian yang menunjukkan hasil kontradiktif. Cambridge Heart Antioxidant Study (CHAOS) membuktikan adanya penurunan bermakna dari kejadian infark miokard non-fatal pada pasien yang mengkonsumsi vitamin E 400-800 IU/hari dibandingkan dengan pasien yang mendapat plasebo (43). Di sisi lain, Heart Outcomes Prevention Evaluation (HOPE) gagal mengkonfirmasi manfaat positif dari vitamin E (44). Penelitian lain menunjukkan bahwa konsumsi vitamin $\mathrm{E}$ dosis tinggi ( $\geq 400 \mathrm{IU})$ secara jangka panjang dapat meningkatkan angka mortalitas dengan berbagai penyebab, diduga karena sifat pro-oksidan dari vitamin $\mathrm{E}$ dosis tinggi. Penelitian Miller et al (2005) tersebut memiliki keterbatasan, diantaranya subjek penelitian terbatas pada pasien dengan penyakit kronis (45), di mana kerusakan yang terjadi umumnya sudah ireversibel. Pada penelitian ini, dengan model pencegahan dan vitamin $\mathrm{E}$ diberikan dalam jangka waktu singkat, dibuktikan bahwa suplementasi vitamin E $50 \mu \mathrm{M}$ pada EPC dengan atau tanpa perlakuan glukosa tidak bersifat sebagai prooksidan, di mana tidak terjadi peningkatan ROS maupun penurunan NO. Oleh karena itu penelitian terhadap

\section{DAFTAR PUSTAKA}

1. Mihardja L, Delima, Manz HS, Gani L, and Soegondo S. Prevalence and Determinants of Diabetes Mellitus and Impaired Glucose Tolerance in Indonesia (A Part of Basic Health Research/RISKESDAS). Acta Medica Indonesiana. 2009; 41(4): 169-174.

2. Choi YJ, Lim HS, Choi JS, et al. Blockade of Chronic High Glucose-Induced Endothelial Apoptosis by Sasa Borealis Bamboo Extract. Experimental Biology and Medicine. 2008; 233(5): 580-591.

3. Shantsila E, Watson T, and Lip GYH. Endothelial Progenitor Cells in Cardiovascular Disorders. Journal of the American College of Cardiology. 2007; 49: 741752.

4. Yoon $\mathrm{CH}$, Hur J, Park $\mathrm{K}$, et al. Synergistic Neovascularization by Mixed Transplantation of Early Endothelial Progenitor Cells and Late Outgrowth Endothelial Cells: The Role of Angiogenic Cytokines and Matrix Metalloproteinases. Circulation. 2005; 112: 1618-1627.

5. You D, Waeckel L, Ebrahimian TG, et al. Increase In Vascular Permeability and Vasodilation are Critical for Proangiogenic Effects of Stem Cell Therapy. Circulation. 2006; 114(4): 328-338.

6. Lamalice L, Le Boeuf F, and Huot J. Endothelial Cell Migration During Angiogenesis. Circulation Research. 2007; 100: 782-794.

7. Schmidt A, Brixius K, and Bloch W. Endothelial Precursor Cell Migration During Vasculogenesis. Circulation Research. 2007; 101: 125-136. toksisitas vitamin E perlu lebih banyak dikembangkan agar dapat diperoleh dosis vitamin E yang tepat untuk dapat digunakan sebagai penunjang terapi penyakit vaskuler pada DM. Selain itu, untuk mengoptimalkan peran EPC dalam pengobatan regeneratif penyakit vaskuler pada DM juga perlu dikembangkan penelitian menggunakan substansi alam yang berpotensi sebagai antioksidan dan donor NO.

Model kultur EPC dengan kondisi glukosa tinggi digunakan untuk simulasi hiperglikemia klinis dalam evaluasi fungsi EPC in vitro. Konsentrasi glukosa pada media sebesar 4,5-5 $\mathrm{mM}$ sebanding dengan kadar glukosa darah 80-89 mg/dl, dan konsentrasi glukosa pada media sebesar $22 \mathrm{mM}$ sesuai dengan kadar glukosa darah $400 \mathrm{mg} / \mathrm{dL}$ yang dapat terjadi pada pasien DM tidak terkontrol $(21,46)$. Meskipun pemaparan glukosa selama 24 jam tidak sesuai dengan patologi EPC pada pasien yang telah menderita DM secara kronis, tetapi model in vitro ini dapat diterima dengan tujuan untuk mempelajari mekanisme disfungsi EPC pada kondisi hiperglikemia (47). Dapat disimpulkan bahwa pemberian vitamin E dapat mempertahankan kemampuan EPC yang dipapar glukosa tinggi dalam melepaskan NO dan menginduksi migrasi sel endotel melalui mekanisme yang terkait dengan ROS.

\section{UCAPAN TERIMA KASIH}

Penelitian ini didanai oleh UPP Fakultas Kedokteran Universitas Brawijaya.

8. Kobayashi T, Taguchi K, Takenouchi Y, Matsumoto T, and Kamata K. Insulin-Inducedimpairment Via Peroxynitrite Production of Endothelium-Dependent Relaxation and Sarco/Endoplasmic Reticulum $\mathrm{Ca}(2+)$ Atpase Function in Aortas from Diabetic Rats. Free Radical Biology and Medicine. 2007; 43(3): 431-443.

9. Szabo C. Role of Nitrosative Stress in the Pathogenesis of Diabetic Vascular Dysfunction. British Journal of Pharmacology. 2009; 156(5): 713-727.

10. Srinivasan S, Hatley ME, Bolick DT, et al. Hyperglycaemia-Induced Superoxide Production Decreases Enos Expression Via AP-1 Activation in Aortic Endothelial Cells. Diabetologia. 2004; 47: 1727-1734.

11. Du XL, Edelstein D, Dimmeler S, Ju Q, Sui C, and Brownlee M. Hyperglycaemia Inhibits Endothelial Nitric Oxide Synthase Activity by Posttranslational Modification at the Akt Site. The Journal of Clinical Investigation. 2001; 108(9): 1341-1348.

12. Morales-Ruiz M, Fulton D, Sowa G, et al. Vascular Endothelial Growth Factor-Stimulated Actin Reorganization and Migration of Endothelial Cells is Regulated Via the Serine/Threonine Kinase Akt. Circulation Research. 2000; 86(8): 892-896.

13. Srivastava SK, Ramana KV, and Bhatnagar A. Role of Aldose Reductase and Oxidative Damage in Diabetes and the Consequent Potential for Therapeutic Options. Endocrine Reviews. 2005; 26(3): 380-392.

14. Schalkwijk CG and Stehouwer CD. Vascular Complications in Diabetes Mellitus: The Role of 
Endothelial Dysfunction. Clinical Science. 2005; 109(2): 143-159.

15. Aalst JA, Zhang D, Miyazaki K, Colles SM, Fox PL, and Graham LM. Role of Reactive Oxygen Species in Inhibition of Endothelial Cell Migration by Oxidized Low-Densitylipoprotein. Journal Vascular Surgery. 2004; 40(16): 1208-1215.

16. Zheng $\mathrm{ZZ}$ and Liu ZX. Activation of the Phosphatidylinositol 3-Kinase/Protein Kinase Akt Pathway Mediates Nitric Oxide-Induced Endothelial Cell Migration and Angiogenesis. The International Journal of Biochemistry and Cell Biology. 2007; 39(2): 340-348.

17. Ulker S, McKeown PP, and Bayraktutan U. Vitamins Reverse Endothelial Dysfunction through Regulation of Enos and NAD(P)H Oxidase Activities. Hypertension. 2003; 41(3): 534-539.

18. Ganz MB and Seftel A. Glucose-Induced Changes in Protein Kinase $C$ and Nitric Oxide are Prevented by Vitamin E. American Journal of Phisiology Endocrinology and Metabolism. 2000; 278(1): 146-152.

19. Tepper OM, Galiano RD, Capla JM, et al. Human Endothelial Progenitor Cells From Type II Diabetics Exhibit Impaired Proliferation, Adhesion, and Incorporation Into Vascular Structures. Circulation. 2002; 106(22): 2781-2786.

20. Fadini GP, Agostini C, and Avogaro A. Endothelial Progenitor Cells and Vascular Biology in Diabetes Mellitus, Current Knowledge and Future Perspective. Current Diabetes Review. 2005; 1(1): 41-58.

21. Chen YH, Lin SJ, Lin FY, et al. High Glucose Impair Early and Late Endothelial Progenitor Cell by Modifying Nitric Oxide-Related but Not Oxidative Stress Mediated Mechanism. Diabetes. 2007; 56(6): 15591568.

22. Khotimah $\mathrm{H}$, Widodo MA, and Karyono S. Effect of Vitamin E and Vitamin C Towards Bioavailability of Endothelial Nitric Oxide, Malondialdehid Level and Cell Density in High Glucose Condition. 4th Congress of Pharmacology. Bali, 2004.

23. Olson SE and Seidel GE Jr. Culture of In Vitro-Produced Bovine Embryos with Vitamin E Improves Development In Vitro and After Transfer to Recipients. Biology of Reproduction. 2000; 62(2): 248-252.

24. Permatasari N, Widodo MA, and Sumitro SB. High Glucose Concentration Increase Basal Calcium Intracellular Concentration ([Ca2+]) in Human Umbilical Vein Endothelial Cells (HUVECS) Cultured. Journal Asian Federation on Endocrine Societies. 2002; 2(1): 139-141.

25. Esfandiari N, Sharma RK, Saleh RA, Thomas AJ, and Agarwal A. Utility of the Nitroblue Tetrazolium Reduction Test for Assessment of Reactive Oxygen Species Production Byseminal Leukocytes and Spermatozoa. Journal of Andrology. 2003; 24(6): 862-870.

26. Langer H, May AE, Daub K, et al. Adherent Platelets Recruit and Induce Differentiation of Murine Embryonic Endothelial Progenitor Cells to Mature
Endothelial Cells In Vitro. Circulation Research. 2006; 98(2): e2-10.

27. Scharner D. The Non-apoptotic Function of Caspase-8 in Endothelial Precursor Cells. [Disertasi]. Johann Wolfgang Goethe-Universität, Frankfurt. 2009.

28. Ding QF, Hayashi T, Packiasamy ARJ, et al. The Effect of High Glucose on $\mathrm{NO}$ and $\mathrm{O}_{2}^{-}$through Endothelial GTPCH1 and NADPH Oxidase. Life Sciences. 2004; 75(26): 3185-3194.

29. Romero MJ, Platt DH, Tawfik HE, et al. Diabetesinduced Coronary Vascular Dysfunction InvolvesIncreased Arginase Activity. Circulation Research. 2008; 102(1): 95-102.

30. Venugopal SK, Devaraj S, Yang T, and Jialal I. ATocopherol Decreases Superoxide Anion Release in Human Monocytes Under Hyperglycemic Conditions Via Inhibition of Protein Kinase C-A. Diabetes. 2002; 51(10): 3049-3054.

31. Rupin A, Paysant J, Sansilvestri-Morel P, et al. Role of NADPH Oxidase-Mediated Superoxide Production in the Regulation of E-Selectin Expression by Endothelial Cells Subjected to Anoxia/Reoxygenation. Cardiovascular Research. 2004; 63(2): 323-330.

32. Camici GG, Schiavoni M, Francia P, et al. Genetic Deletion of P66(Shc) Adaptor Protein Prevents Hyperglycemia-Induced Endothelial Dysfunction and Oxidative Stress. Proceeding of National Academy of Sciences of the United States of America. 2007; 104(12): 5217-5222.

33. Ouedraogo $\mathrm{R}, \mathrm{Wu} \mathrm{X}, \mathrm{Xu} \mathrm{S}$, et al. Adiponectin Suppression of High-Glucose-Induced Reactive Oxygen Species in Vascular Endothelial Cells Evidence for Involvement of a Camp Signaling Pathway. Diabetes. 2006; 55(6): 1840-1846.

34. Halliwell B and Gutteridge JMC. Free Radicals in Biology and Medicine. Oxford: University Press; 1999.

35. Suvorava T, Kumpf S, Rauch BH, Dao VT, Adams V, and Kojda G. Hydrogen Peroxide Inhibits Exercise-Induced Increase of Circulating Stem Cells with Endothelial Progenitor Capacity. Free Radical Research. 2010; 44(2): 199-207.

36. Takacs P, Kauma SW, Sholley MM, Walsh SW, Dinsmoor MJ, and Green K. Increased Circulating Lipid Peroxides in Severe Preeclampsia Activate NF-Kb and Upregulate ICAM-1 in Vascularendothelial Cells. The Journal of the Federation of American Societies for Experimental Biology. 2001; 15(2): 279-281.

37. Okamoto T, Schlegel A, Schere PE, and Lisanti MP. Caveolin a Family of Scaffolding Protein for Organizing 'Preassembled Signaling Complexes' at the Plasma Membrane. The Journal of Biological Chemistry. 1998; 273(10): 5419-5422.

38. Mineo C and Shaul PW. Circulating Cardiovascular Disease Risk Factors and Signaling in Endothelial Cell Caveolae. Cardiovascular Research. 2006; 70(1): 3141.

39. Maniatis NA, Brovkovych V, Allen SE, et al. Novel Mechanism of Endothelial Nitric Oxide Synthase Activation Mediated by Caveolae Internalization in 
Endothelial Cells. Circulation Research. 2006; 99(8): 870-877.

40. Labrecque L, Royal I, Surprenant DS, Patterson C, Gingras D, and Béliveau R. Regulation of Vascular Endothelial Growth Factor Receptor-2 Activity by Caveolin-1 and Plasma Membrane Cholesterol. Molecular Biology of the Cell. 2003; 14(1): 334-347.

41. Navarro A, Anand-Apte B, Parat MO. A Role for Caveolae in Cell Migration. The Journal of the Federation of American Societies for Experimental Biology. 2004; 18(15): 1801-1811.

42. Sonveaux $\mathrm{P}$, Martinive $\mathrm{P}$, DeWever J, et al. Caveolin-1 Expression is Critical for Vascular Endothelial Growth Factor-Induced Ischemic Hindlimb Collateralization and Nitric Oxide-Mediated Angiogenesis. Circulation Research. 2004; 95(2): 154-161.

43. Stephens NG, Parsons A, Schofield PM, Kelly F, Cheeseman K, and Mitchinson MJ. Randomised controlled trial of vitamin $E$ in patients with coronary disease: Cambridge Heart Antioxidant Study (CHAOS). The Lancet. 1996; 347(9004): 781-786.

44. Kleinert S. HOPE for Cardiovascular Disease Prevention with ACE Inhibitor Ramipril. The Lancet. 1999; 354(9181): 841.

45. Miller ER, Pastor-Barriuso R, Dalal D, Riemersma RA, Appel LJ, and Guallar E. Meta-Analysis: High-Dosage Vitamin E Supplementation May Increase All-Cause Mortality. Annas of Internal Medicine. 2005; 142(1): 37-46.

46. Zhang W, Wang XH, Chen SF, et al. Biphasic Response of Endothelial Progenitor Cell Proliferation Induced By High Glucose and its Relationship with Reactive Oxygen Species. Journal of Endocrinology. 2008; 197(3): 463-470.

47. Shenouda SM, Widlansky ME, Chen K, et al. Altered Mitochondrial Dynamics Contributes to Endothelial Dysfunction in Diabetes Mellitus. Circulation. 2011; 124(4): 444-453. 